\title{
KEBUTUHAN GURU PEMINATAN KEJURUAN DAN PEMENUHANNYA
}

\section{REQUIREMENTS FOR VOCATIONAL TEACHERS AND FULFILLING}

\author{
Teguh Supriyadi \\ Pusat Penelitian Kebijakan Pendidikan dan Kebudayaan, \\ Kementerian Pendidikan dan Kebudayaan \\ e-mail : supriyadi_teg@yahoo.co.id
}

\begin{abstract}
ABSTRAK
Penelitian ini bertujuan mengetahui kebutuhan guru SMK dan mengidentifikasi upaya-upaya pemenuhan kebutuhan guru SMK. Penelitian menggunakan pendekatan kuantitatif dengan analisis bersumber dari data sekunder. Hasil penelitian memperlihatkan bahwa kebutuhan guru peminatan kejuruan masuk dalam ketegori kekurangan, baik di sekolah negeri maupun swasta, tetapi kekurangan guru di sekolah swasta lebih besar daripada di sekolah negeri. Upaya pemenuhan guru peminatan kejuruan telah dilakukan, antara lain: rekrutmen guru PNS, rekrutmen guru honorer, maupun program keahlian ganda, tetapi masih memerlukan pemikiran lebih lanjut untuk mengatasinya. Pemenuhan kebutuhan guru peminatan kejuruan dapat dilakukan dengan memprioritaskan rekrutmen guru Pegawai Pemerintah dengan Perjanjian Kerja (PPPK), Selain itu, dapat pula melibatkan dosen di universitas/politeknik, melibatkan pekerja dari dunia usaha/dunia industri dan orang-orang yang memiliki pengetahuan dan keterampilan tapi tidak mempunyai sertifikat formal mengajar untuk mengajar mata pelajaran muatan peminatan kejuruan.
\end{abstract}

Kata Kunci: Guru Peminatan Kejuruan, Sekolah Menengah Kejuruan, Pemenuhan Kebutuhan Guru

\section{ABSTRACT}

This study aims to determine the needs of vocational school teachers and to identify the efforts to fulfill the needs of vocational school teachers. The research used a quantitative approach with a secondary data analysis method. The results of the study show that the needs of specialized vocational teachers could be categorized as a shortage, in both state and private schools, while the shortage in private schools is greater than state schools. Efforts to fulfill specialized vocational teachers have been carried out by the government, including: Recruitment of Civil servant (PNS) Teacher and Recruitment of Honorary Teacher, and also Dual Expertise Program, but still needs further thought to overcome them. The needs of specialized vocational teachers could be fulfilled by prioritizing recruitment of teachers as Government Employees with Work Agreements (PPPK). In addition, it could also involving lecturers at universities/polytechnics, involving workers from the business world/industry and people who have knowledge and skills but do not have formal teaching certificates to teach specialized vocation subjects.

Keywords: Vocational Specialization Teachers, Vocational High Schools, Meeting Teacher Needs 


\section{PENDAHULUAN}

Salah satu amanat Inpres No. 9 Tahun 2016 Tentang Revitalisasi Sekolah Menengah Kejuruan Dalam Meningkatkan Kualitas Dan daya Saing Sumber Daya Manusia Indonesia adalah meningkatkan jumlah dan kompetensi bagi pendidik dan tenaga kependidikan Sekolah Menengah Kejuruan (SMK). Keberadaan guru sangat penting sehingga ketersediaan guru harus cukup, mengingat keberadaannya untuk mendukung melaksanakan tugas utama mendidik, mengajar, membimbing, mengarahkan, melatih, menilai, dan mengevaluasi peserta didik pada pendidikan anak usia dini jalur pendidikan formal, pendidikan dasar, dan pendidikan menengah. Kekurangan guru berdampak pada mutu pendidikan, khususnya dalam mutu proses dan mutu lulusan. Ketersediaan guru yang cukup merupakan kunci utama bagi keberlangsungan pembelajaran yang baik pada setiap lembaga pendidikan. Tanpa guru, pendidikan hanya akan menjadi slogan muluk karena segala bentuk kebijakan dan program pada akhirnya akan ditentukan oleh kinerja pihak yang berada di garis terdepan, yaitu guru (Wiharna, 2006:64 dalam Triwiyanto, T., Desi Eri Kusumaningrum, dan Imam Gunawan, 2017).

Saat ini, spektrum dan kurikulum SMK telah mengalami perubahan. Peraturan Direktur Jenderal Pendidikan Dasar Dan Menengah Kementerian Pendidikan Dan Kebudayaan Nomor: 06/D.D5/KK/2018 Tentang Spektrum Keahlian Sekolah Menengah Kejuruan (SMK)/Madrasah Aliyah Kejuruan (MAK), menyatakan bahwa bidang keahlian di SMK/MAK meliputi; (1) Teknologi dan Rekayasa, (2) Energi dan
Pertambangan, (3) Teknologi Informasi dan Komunikasi, (4) Kesehatan dan Pekerjaan Sosial, (5) Agribisnis dan Agroteknologi, (6) Kemaritiman, (7) Bisnis dan Manajemen, (8) Pariwisata, dan (9) Seni dan Industri Kreatif. Dari sembilan bidang keahlian tersebut dijabarkan ke dalam 49 program keahlian dan 146 kompetensi keahlian (Tabel 1).

Tabel 1. Spektrum Keahlian Di SMK/MAK

\begin{tabular}{|c|c|c|c|c|c|}
\hline No & Bidang Keahlian & $\begin{array}{l}\text { Jumlah } \\
\text { Program } \\
\text { Keahlian }\end{array}$ & & $\begin{array}{l}\text { Jumlah } \\
\text { Kompetensi } \\
\text { Keahlian }\end{array}$ & \\
\hline 1 & $\begin{array}{l}\text { Teknologi dan } \\
\text { Rekayasa }\end{array}$ & & 13 & & 58 \\
\hline 2 & $\begin{array}{l}\text { Energi dan } \\
\text { Pertambangan }\end{array}$ & & 3 & & 6 \\
\hline 3 & $\begin{array}{l}\text { Teknologi Informasi } \\
\text { dan Komunikasi }\end{array}$ & & 2 & & 6 \\
\hline 4 & $\begin{array}{l}\text { Kesehatan dan } \\
\text { Pekerjaan Sosial }\end{array}$ & & 5 & & 7 \\
\hline 5 & $\begin{array}{l}\text { Agribisnis dan } \\
\text { Agroteknologi }\end{array}$ & & 6 & & 20 \\
\hline 6 & Kemaritiman & & 4 & & 10 \\
\hline 7 & $\begin{array}{l}\text { Bisnis dan } \\
\text { Manajemen }\end{array}$ & & 4 & & 7 \\
\hline 8 & Pariwisata & & 4 & & 9 \\
\hline 9 & $\begin{array}{l}\text { Seni dan Industri } \\
\text { Kreatif }\end{array}$ & & 8 & & 23 \\
\hline \multicolumn{2}{|c|}{ Total } & & 49 & & 146 \\
\hline
\end{tabular}

Sumber Data: Peraturan Direktur Jenderal Pendidikan Dasar Dan Menengah Kementerian Pendidikan Dan Kebudayaan Nomor: 06/D.D5/KK/2018 Tentang Spektrum Keahlian Sekolah Menengah Kejuruan (SMK)/Madrasah Aliyah Kejuruan (MAK)

Selanjutnya, dalam Peraturan Direktur Jenderal Pendidikan Dasar Dan Menengah Nomor: 07/D.D5/KK/2018 Tentang Struktur Kurikulum Sekolah Menengah Kejuruan (SMK)/Madrasah Aliyah Kejuruan (MAK) disebutkan bahwa mata pelajaran di SMK/ MAK di kelompokan menjadi tiga kelompok mata pelajaran, yaitu: (1) muatan nasional, (2) muatan kewilayahan, dan (3) muatan peminatan kejuruan (Tabel 2). Sementara pada tahun-tahun sebelumnya, mata pelajaran di SMK/MAK dikelompokkan menjadi: 
(1) normatif, (2) adaptif, dan (3) produktif (Permendiknas Nomor 22 Tahun 2006 Tentang Standar Isi Untuk Satuan Pendidikan Dasar Dan Menengah).

Tabel 2. Kelompok Mata Pelajaran di SMK/ MAK

\begin{tabular}{lll} 
& & MAK \\
\hline No & $\begin{array}{l}\text { Kelompok Mata } \\
\text { Pelajaran }\end{array}$ & Mata Pelajaran \\
\hline 1 & Muatan Nasional & $\cdot$ Pendidikan Agama dan Budi \\
& & Pekerti \\
& & Pendidikan Pancasila dan \\
& & Kewarganegaraan \\
& & Bahasa Indonesia \\
& & Matematika \\
& & $\cdot$ Sejarah Indonesia \\
& & $\cdot$ Bahasa Inggris \\
\hline 2 & Muatan & \\
& kewilayahan & $\cdot$ Seni Budaya \\
& & Pendidikan Jasmani, Olahraga dan \\
& & Kesehatan \\
\hline \multirow{2}{*}{$\begin{array}{l}\text { Muatan peminatan } \\
\text { kejuruan }\end{array}$} & Dasar Bidang keahlian (C1) \\
& & Dasar program keahlian (C2) \\
& & Kompetensi keahlian (C3) \\
\hline
\end{tabular}

Sumber Data: Peraturan Direktur Jenderal Pendidikan Dasar Dan Menengah Nomor: 07/D.D5/Kk/2018 Tentang Struktur Kurikulum Sekolah Menengah Kejuruan (SMK)/Madrasah Aliyah Kejuruan (MAK)

Dengan memperhatikan amanat Inpres No. 9 Tahun 2016 serta perubahan spektrum dan kurikulum SMK, diduga kuat bahwa ketersediaan guru peminatan kejuruan masih menjadi persoalan. Dapodik per 31 Desember 2018 (diolah Ditjen. GTK, Kemendikbud) memperlihatkan adanya kesenjangan guru peminatan kejuruan, antara jumlah guru yang ada dengan jumlah guru yang ideal (seharusnya). Pada SMK negeri jumlah guru yang ada 62.105 guru, sementara jumlah guru yang ideal 88.091 guru. Pada SMK swasta jumlah guru yang ada 54.238 guru, sementara jumlah guru yang ideal 119.513 guru.

Untuk itulah tulisan ini diketengahkan, sebagai bagian dari hasil kajian yang dilakukan. Secara eksplisit tujuan yang ingin diketahui adalah mengetahui kebutuhan guru peminatan kejuruan dan mengemukakan alternatif upaya pemenuhannya.

\section{KAJIAN LITERATUR}

\section{Kebutuhan Guru}

Dalam Peraturan Direktur Jenderal Pendidikan Dasar Dan Menengah Nomor: 07/D.D5/KK/2018 disebutkan bahwa mata pelajaran di SMK/MAK di kelompokan menjadi tiga kelompok mata pelajaran, yaitu: (1) muatan nasional, (2) muatan kewilayahan, dan (3) muatan peminatan kejuruan. Terkait dengan guru peminatan kejuruan, guru peminatan kejuruan adalah guru pengampu mata pelajaran muatan kejuruan. Guru peminatan kejuruan dahulu disebut dengan guru produktif (Permendiknas Nomor 22 Tahun 2006).

Kebutuhan guru peminatan kejuruan dapat diketahui bila kita mengetahui jumlah guru yang ideal dan jumlah guru yang ada (tersedia). Menurut Triwiyanto, T., Desi Eri Kusumaningrum, dan Imam Gunawan (2017), kebutuhan guru adalah kesenjangan antara guru yang ada sekarang dan bagaimana hal itu seharusnya atau kesenjangan antara guru yang ada sekarang dengan seharusnya diperlukan. Dengan demikian, kebutuhan guru dapat bernilai negatif (kekurangan guru) atau positif (kelebihan guru).

\section{Faktor yang Mempengaruhi \\ Kebutuhan Guru}

Banyak faktor yang mempengaruhi kebutuhan guru. Fakry Gaffar (1989) dalam Eni Kusrini, E (2014) menyebutkan beberapa faktor yang diperhitungkan dalam melakukan proyeksi kebutuhan guru sebagai data dasar yang mencakup: (1) enrollment sekolah, (2) jumlah jam per minggu yang diterima siswa masing-masing mata pelajaran tertentu maupun seluruh mata pelajaran, (3) beban mengajar penuh guru per minggu, (4) besar kelas yang dianggap efektif untuk menerima 
suatu mata pelajaran, (5) jumlah guru yang ada, (6) jumlah guru yang akan pensiun atau berhenti atau karena sesuatu hal akan meninggalkan jabatan keguruan, dan (7) jenis sekolah dan jenjang sekolah yang memerlukan guru. Sementara, Chandra I, Aunurrahman, Herculanus Bahari Sindju (tanpa tahun) dalam penelitiannya mengemukakan beberapa faktor perhitungan proyeksi kebutuhan guru, yakni: (1) pertumbuhan enrolmen (siswa), (2) mutasi siswa, (3) siswa drop out, (4) pertumbuhan guru, dan (5) guru pensiun.

\section{Dampak Kekurangan Guru Peminatan} Kejuruan

Muhson (2004) dalam Triwiyanto, T., Desi Eri Kusumaningrum, dan Imam Gunawan (2017) menegaskan bahwa guru sebagai pihak yang berhubungan langsung dalam proses pembelajaran di kelas memiliki peran yang penting dalam meningkatkan kualitas anak didiknya. Guru, baik secara kuantitas dan kualitas guru penting dalam membentuk kualitas peserta didik. Hal ini dikarenakan peran guru yang sangat strategis, yakni adalah mendidik, mengajar, membimbing, mengarahkan, melatih, menilai, dan mengevaluasi peserta didik pada pendidikan anak usia dini jalur pendidikan formal, pendidikan dasar, dan pendidikan menengah.

Salah satu dari 10 tren vokasi yang harus diawasi adalah minimnya ketersediaan alat dan guru kejuruan minim, sedangkan demand nya tinggi. Kecenderungan sekolah vokasi untuk menawarkan jurusan dan kompetensi yang mudah diajarkan (kebutuhan alat dan guru kejuruan minim), sedangkan permintaan akan jurusan tersebut besar. Hal ini akan berdampak pada lulusan vokasi yang tidak mempunyai daya saing dan nilai tambah dibandingkan dengan lulusan SMA ataupun lulusan perguruan tinggi (Yulius, Muhammad Isran, Mardhianda WP, dan Bangkit Anugerah, 2017). Mereka juga menegaskan bahwa dari sisi kualitas, 78\% dari guru SMK merupakan guru normatifadaptif dan hanya $22 \%$ yang merupakan guru produktif untuk pelajaran kejuruan. Dengan persentase guru normatif-adaptif yang lebih tinggi dibandingkan pengajar yang memang secara khusus memiliki kompetensi di bidang kejuruannya, hal ini bisa menjadi salah satu ancaman rendahnya daya saing lulusan SMK.

Gambar 1 menyajikan Persentase Tingkat Pengangguran Terbuka (TPT). SMK menduduki peringkat satu dalam penyumbang pengangguran terbuka, kemudian diikuti SMA, Diploma I/II/III/ Akademi, Universitas. 


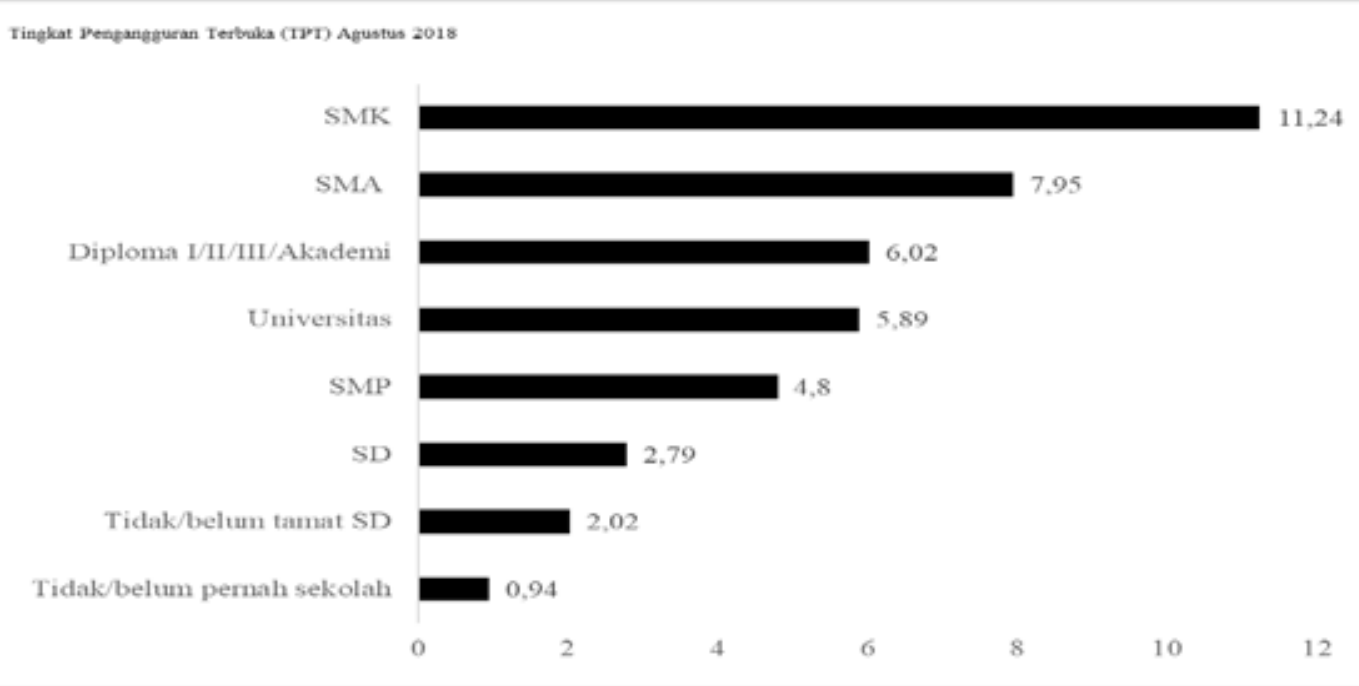

Gambar 1. Persentase Tingkat Pengangguran Terbuka (TPT) Agustus 2018 Sumber Data: Keadaan Angkatan Kerja Di Indonesia Agustus 2018, Badan Pusat Statistik, 2018

4. Hasil-Hasil Penelitian Yang Terkait Dengan Kebutuhan Guru Peminatan Kejuruan

Yahya, M. (2016) dalam kajiannya yang berjudul Strategi Pemenuhan Kebutuhan Guru Produktif SMK menyimpulkan bahwa (1) analisis beban kerja guru produktif merupakan suatu kegiatan yang meliputi perhitungan kebutuhan guru produktif SMK berdasarkan penjabaran dari kegiatan pembelajaran atau tatap muka per jenis guru per minggu, kemudian dibagi dengan jumlah yakni 24 jam kali tatap muka, dimana alokasi jam pelajaran per minggu pada satuan pendidikan, (2) pemetaan guru produktif SMK merupakan suatu kebijakan atau wewenang pemerintah dalam mendistribusi dan memenuhi kebutuhan guru berdasarkan karakteristik dan kebutuhan kota/kabupaten dan provinsi secara nasional, (3) pemerataan guru produktif SMK merupakan suatu kebijakan pemerintah dalam meningkatkan sumber daya manusia dalam hal tenaga pendidik atau guru produktif pada satuan pendidikan tingkat SMK secara nasional, (4) pengadaan guru produktif SMK merupakan suatu model yang terjabarkan dalam suatu mekanisme untuk memenuhi kebutuhan guru berdasarkan karakteristik dan kebutuhan pada satuan pendidikan SMK melalui: proses pengangkatan guru produktif SMK, retribusi Guru Produktif SMK, dan pengadaan guru produktif SMK untuk pemenuhan guru secara cepat seperti program Talent Scouting, Program Sarjana Mengajar dan Program Pendampingan SMK. Selain itu, Mulyadi Y, Agus Setiawan, dan Purnawan (2010) dalam penelitiannya yang berjudul Studi Evaluasi Kebutuhan Guru Sekolah Menengah Kejuruan Di Propinsi Bangka Belitung menimpulkan bahwa terdapat kelebihan jumlah guru sebanyak 223 orang dengan rincian kelebihan jumlah guru normatif sebanyak 173 orang dan guru adaptif sebanyak 98 orang, sedangkan untuk guru produktif masih kekurangan sebanyak 82 orang. Rekomendasi yang dapat disampaikan yaitu: melakukan redistribusi guru kejuruan dari kota besar ke daerah, 
melakukan alih kompetensi mengajar guru adaptif/normatif menjadi guru produktif atau melakukan rekruitmen guru produktif baru, dan melakukan KKN tematik bagi mahasiswa pada program keahlian yang relevan dengan SMK.

\section{METODE PENELITIAN}

Kajian ini dilakukan dengan pendekatan penelitian kuantitatif dengan metode analisis data sekunder. Menurut Heaton dalam Amirin, T. M. (2015), analisis data sekunder merupakan suatu strategi penelitian yang memanfaatkan data kuantiatif ataupun kualitatif yang sudah ada untuk menemukan permasalahan baru atau menguji hasil penelitian terdahulu.

Penelitian analisis data sekunder itu relatif pendek. M. Katherine McCaston (2005) dalam Amirin, T. M. (2015) menyatakan bahwa analisis data sekunder itu mencakup dua proses pokok, yaitu mengumpulkan data dan menganalisisnya

\section{Pengumpulan Data}

Variabel, data yang diperlukan, dan sumber data dalam kajian ini disajikan dalam tabel 3 .

Tabel 3. Tujuan Kajian, Variabel, Data

\section{Analisis Data}

Teknik analisis data lebih bersifat deskriptif, dalam arti disajikan dalam bentuk tabel statistik deskriptif kemudian dianalisis secara kualitatif untuk mengemukakan temuan-temuan dan mengemukakan alternatif pemikiran penyelesaian masalah.

\section{HASIL DAN PEMBAHASAN}

\section{Hasil}

1.1. Kebutuhan Guru Peminatan Kejuruan

Berdasarkan Dapodik per 31 Desember 2018 (diolah Ditjen. GTK, Kemendikbud) diketahui bahwa jumlah guru yang ada saat ini mencapai 116.343 guru, yang terdiri atas: di SMK negeri berjumlah 62.105 guru dan di SMK swasta berjumlah 54.238 guru. Jumlah guru yang ideal 207.604 guru, yang terdiri atas: di SMK negeri berjumlah 88.091 guru dan di SMK swasta berjumlah 119.513 guru. Jumlah guru yang ada saat ini lebih kecil dibandingkan jumlah guru yang ideal. Ini mengindikasikan kebutuhan guru peminatan kejuruan dalam kategori kekurangan (tanda -). Kekurangan guru peminatan di SMK negeri sebanyak 27.164 guru, sementara di SMK swasta sebanyak 66.378 guru (Tabel $4)$.

Yang Diperlukan, dan Sumber Data

\begin{tabular}{lllll}
\hline No & Tujuan Kajian & Variabel & $\begin{array}{l}\text { Data Yang } \\
\text { Diperlukan }\end{array}$ & Sumber Data \\
\hline 1 & $\begin{array}{l}\text { Mengetahui } \\
\text { kebutuhan guru } \\
\text { peminatan kejuruan }\end{array}$ & $\begin{array}{l}\text { Kebutuhan } \\
\text { guru }\end{array}$ & $\begin{array}{l}\text { Jumlah guru yang } \\
\text { ideal }\end{array}$ & $\begin{array}{l}\text { Ditjen. GTK, Kemendikbud (Dapodik } \\
\text { 31 Desember 2018, diolah Ditjen. GTK) }\end{array}$ \\
\cline { 3 - 4 } & & $\begin{array}{l}\text { Jumlah guru yang } \\
\text { ada saat ini }\end{array}$ & $\begin{array}{l}\text { PDSPK, Setjen, Kemendikbud(Dapodik } \\
\text { 31 Desember 2018) }\end{array}$ \\
\hline $\begin{array}{l}\text { Mengetahui upaya- } \\
\text { upaya pemenuhan } \\
\text { kebutuhan guru } \\
\text { peminatan kejuruan } \\
\text { yang telah dilakukan }\end{array}$ & $\begin{array}{l}\text { Upaya-upaya } \\
\text { pemenuhan } \\
\text { kebutuhan } \\
\text { guru peminatan } \\
\text { kejuruan yang } \\
\text { telah dilakukan }\end{array}$ & $\cdot$ Dokumen Kemendikbud \\
\hline
\end{tabular}




\subsubsection{Kebutuhan Guru Peminatan Kejuruan} Menurut Provinsi

Ditinjau dari jumlah kebutuhan guru peminatan kejuruan menurut provinsi, masih memperlihatkan kesenjangan yang

Tabel 4. Persebaran Jumlah Guru Peminatan Kejuruan Yang Ada Saat Ini, Jumlah Guru Yang Ideal, dan Jumlah Kebutuhan Guru (+/-) Menurut Provinsi dan Status Sekolah, Tahun 2018

\begin{tabular}{|c|c|c|c|c|c|c|c|}
\hline Jenjang & Smk & & & Jenjang & Smk & & \\
\hline Status Sekolah & Negeri & & & Status Sekolah & Swasta & & \\
\hline Jenis Mapel & Kejuruan & & & Jenis Mapel & Kejuruan & & \\
\hline Provinsi & $\begin{array}{l}\text { Jumlah guru } \\
\text { yang ada } \\
\text { saat ini }\end{array}$ & $\begin{array}{l}\text { Jumlah } \\
\text { guru yang } \\
\text { ideal }\end{array}$ & $\begin{array}{l}\text { Jumlah } \\
\text { Kebutuhan } \\
\text { guru (+/-) }\end{array}$ & Provinsi & $\begin{array}{l}\text { Jumlah guru } \\
\text { yang ada } \\
\text { saat ini }\end{array}$ & $\begin{array}{l}\text { Jumlah } \\
\text { guru yang } \\
\text { ideal }\end{array}$ & $\begin{array}{l}\begin{array}{l}\text { Jumlah } \\
\text { Kebutuhan } \\
\text { guru (+/-) }\end{array} \\
\end{array}$ \\
\hline Prov. Jawa Barat & 6.182 & 10.655 & -4601 & Prov. Jawa Barat & 12236 & 31522 & -19492 \\
\hline Prov. Jawa Timur & 7916 & 12173 & -4393 & $\begin{array}{l}\text { Prov. Jawa } \\
\text { Tengah } \\
\end{array}$ & 10632 & 21251 & -10834 \\
\hline $\begin{array}{l}\text { Prov. Jawa } \\
\text { Tengah }\end{array}$ & 6432 & 9643 & -3401 & Prov. Jawa Timur & 8426 & 18486 & -10228 \\
\hline $\begin{array}{l}\text { Prov. Sulawesi } \\
\text { Selatan }\end{array}$ & 2757 & 4003 & -1364 & Prov. Banten & 2589 & 7169 & -4629 \\
\hline $\begin{array}{l}\text { Prov. Sumatera } \\
\text { Utara }\end{array}$ & 3877 & 5131 & -1321 & $\begin{array}{l}\text { Prov. Sumatera } \\
\text { Utara }\end{array}$ & 3534 & 7697 & -4242 \\
\hline Prov. Banten & 1467 & 2577 & -1122 & $\begin{array}{l}\text { Prov. D.K.I. } \\
\text { Jakarta }\end{array}$ & 3344 & 6622 & -3408 \\
\hline $\begin{array}{l}\text { Prov. Sumatera } \\
\text { Selatan }\end{array}$ & 1772 & 2535 & -795 & Prov. Lampung & 1992 & 3489 & -1517 \\
\hline Prov. Lampung & 1729 & 2479 & -774 & $\begin{array}{l}\text { Prov. Sulawesi } \\
\text { Selatan }\end{array}$ & 986 & 2269 & -1331 \\
\hline $\begin{array}{l}\text { Prov. Kalimantan } \\
\text { Barat }\end{array}$ & 1241 & 1896 & -667 & $\begin{array}{l}\text { Prov. Sumatera } \\
\text { Selatan }\end{array}$ & 870 & 2068 & -1214 \\
\hline $\begin{array}{l}\text { Prov. Kalimantan } \\
\text { Selatan }\end{array}$ & 1166 & 1736 & -585 & Prov. Bali & 880 & 1946 & -1095 \\
\hline $\begin{array}{l}\text { Prov. Sulawesi } \\
\text { Tengah }\end{array}$ & 1020 & 1585 & -575 & $\begin{array}{l}\text { Prov. D.I. } \\
\text { Yogyakarta } \\
\end{array}$ & 1163 & 2189 & -1059 \\
\hline $\begin{array}{l}\text { Prov. Kalimantan } \\
\text { Timur } \\
\end{array}$ & 1337 & 1890 & -562 & Prov. Riau & 1004 & 1903 & -911 \\
\hline $\begin{array}{l}\text { Prov. Nusa } \\
\text { Tenggara Timur }\end{array}$ & 1811 & 2339 & -550 & $\begin{array}{l}\text { Prov. Nusa } \\
\text { Tenggara Timur }\end{array}$ & 763 & 1590 & -845 \\
\hline $\begin{array}{l}\text { Prov. Sumatera } \\
\text { Barat }\end{array}$ & 2628 & 3126 & -550 & $\begin{array}{l}\text { Prov. Kalimantan } \\
\text { Timur }\end{array}$ & 628 & 1428 & -808 \\
\hline $\begin{array}{l}\text { Prov. Nusa } \\
\text { Tenggara Barat }\end{array}$ & 1693 & 2214 & -537 & $\begin{array}{l}\text { Prov. Sulawesi } \\
\text { Utara }\end{array}$ & 455 & 1009 & -577 \\
\hline $\begin{array}{l}\text { Prov. Sulawesi } \\
\text { Utara }\end{array}$ & 1186 & 1698 & -536 & $\begin{array}{l}\text { Prov. Nusa } \\
\text { Tenggara Barat }\end{array}$ & 563 & 1069 & -509 \\
\hline Prov. Riau & 1985 & 2455 & -489 & $\begin{array}{l}\text { Prov. Sumatera } \\
\text { Barat }\end{array}$ & 469 & 900 & -440 \\
\hline Prov. Bali & 1418 & 1841 & -464 & $\begin{array}{l}\text { Prov. Kalimantan } \\
\text { Barat }\end{array}$ & 468 & 885 & -421 \\
\hline $\begin{array}{l}\text { Prov. D.K.I. } \\
\text { Jakarta }\end{array}$ & 1373 & 1754 & -455 & $\begin{array}{l}\text { Prov. Kepulauan } \\
\text { Riau }\end{array}$ & 306 & 646 & -346 \\
\hline $\begin{array}{l}\text { Prov. D.I. } \\
\text { Yogyakarta }\end{array}$ & 1548 & 1878 & -390 & $\begin{array}{l}\text { Prov. Sulawesi } \\
\text { Tengah }\end{array}$ & 290 & 631 & -344 \\
\hline $\begin{array}{l}\text { Prov. Sulawesi } \\
\text { Tenggara }\end{array}$ & 1037 & 1382 & -355 & $\begin{array}{l}\text { Prov. Kalimantan } \\
\text { Selatan }\end{array}$ & 320 & 609 & -290 \\
\hline Prov. Bengkulu & 883 & 1192 & -322 & Prov. Jambi & 319 & 582 & -266 \\
\hline Prov. Jambi & 1374 & 1677 & -322 & $\begin{array}{l}\text { Prov. Maluku } \\
\text { Utara }\end{array}$ & 137 & 389 & -252 \\
\hline Prov. Papua & 783 & 1066 & -289 & $\begin{array}{l}\text { Prov. Sulawesi } \\
\text { Barat }\end{array}$ & 171 & 417 & -249 \\
\hline
\end{tabular}

menyolok. Provinsi Jawa Barat, Jawa Timur, dan Jawa Tengah merupakan tiga provinsi yang memiliki jumlah kebutuhan guru peminatan kejuruan yang besar (Tabel 4). 


\begin{tabular}{|c|c|c|c|c|c|c|c|}
\hline $\begin{array}{l}\text { Prov. Sulawesi } \\
\text { Barat }\end{array}$ & 606 & 870 & -273 & Prov. Papua & 319 & 565 & -247 \\
\hline $\begin{array}{l}\text { Prov. Kalimantan } \\
\text { Tengah }\end{array}$ & 1019 & 1275 & -269 & $\begin{array}{l}\text { Prov. Sulawesi } \\
\text { Tenggara }\end{array}$ & 145 & 356 & -213 \\
\hline Prov. Maluku & 682 & 908 & -234 & Prov. Maluku & 170 & 326 & -157 \\
\hline $\begin{array}{l}\text { Prov. Maluku } \\
\text { Utara }\end{array}$ & 360 & 563 & -205 & $\begin{array}{l}\text { Prov. Kalimantan } \\
\text { Tengah }\end{array}$ & 192 & 293 & -103 \\
\hline $\begin{array}{l}\text { Prov. Kepulauan } \\
\text { Riau } \\
\end{array}$ & 567 & 756 & -193 & Prov. Aceh & 280 & 371 & -91 \\
\hline $\begin{array}{l}\text { Prov. Kepulauan } \\
\text { Bangka Belitung }\end{array}$ & 556 & 733 & -178 & $\begin{array}{l}\text { Prov. Kepulauan } \\
\text { Bangka Belitung }\end{array}$ & 158 & 234 & -83 \\
\hline Prov. Gorontalo & 626 & 775 & -152 & Prov. Bengkulu & 178 & 236 & -62 \\
\hline Prov. Papua Barat & 372 & 520 & -151 & Prov. Papua Barat & 127 & 176 & -49 \\
\hline Prov. Aceh & 2397 & 2427 & -55 & Prov. Gorontalo & 94 & 130 & -36 \\
\hline $\begin{array}{l}\text { Prov. Kalimantan } \\
\text { Utara }\end{array}$ & 301 & 337 & -37 & $\begin{array}{l}\text { Prov. Kalimantan } \\
\text { Utara }\end{array}$ & 30 & 60 & -30 \\
\hline (blank) & 4 & 2 & 2 & & & & \\
\hline Total & 62.105 & 88.091 & -27.164 & Total & 54.238 & 119.513 & -66.378 \\
\hline
\end{tabular}

Sumber Data: Dapodik per 31 Desember 2018 (diolah Ditjen. GTK, Kemendikbud)

\subsubsection{Kebutuhan Guru Peminatan Kejuruan} Menurut Bidang Keahlian

Ditinjau dari jumlah kebutuhan guru peminatan kejuruan menurut bidang keahlian, masih memperlihatkan kesenjangan yang menyolok. Semua bidang keahlian di SMK negeri maupun swasta mengalami kekurangan guru. Bidang keahlian Teknologi dan Rekayasa, Teknologi Informasi dan Komunikasi, Bisnis dan Manajemen merupakan tiga bidang keahlian yang banyak kekurangan guru. Ini terjadi di SMK negeri maupun swasta (Tabel 5).

Tabel 5. Persebaran Jumlah Guru Peminatan Kejuruan Yang Ada Saat Ini, Jumlah Guru Yang Ideal, dan Jumlah Kebutuhan Guru (+/-) Menurut Bidang Keahlian dan Status Sekolah, Tahun 2018

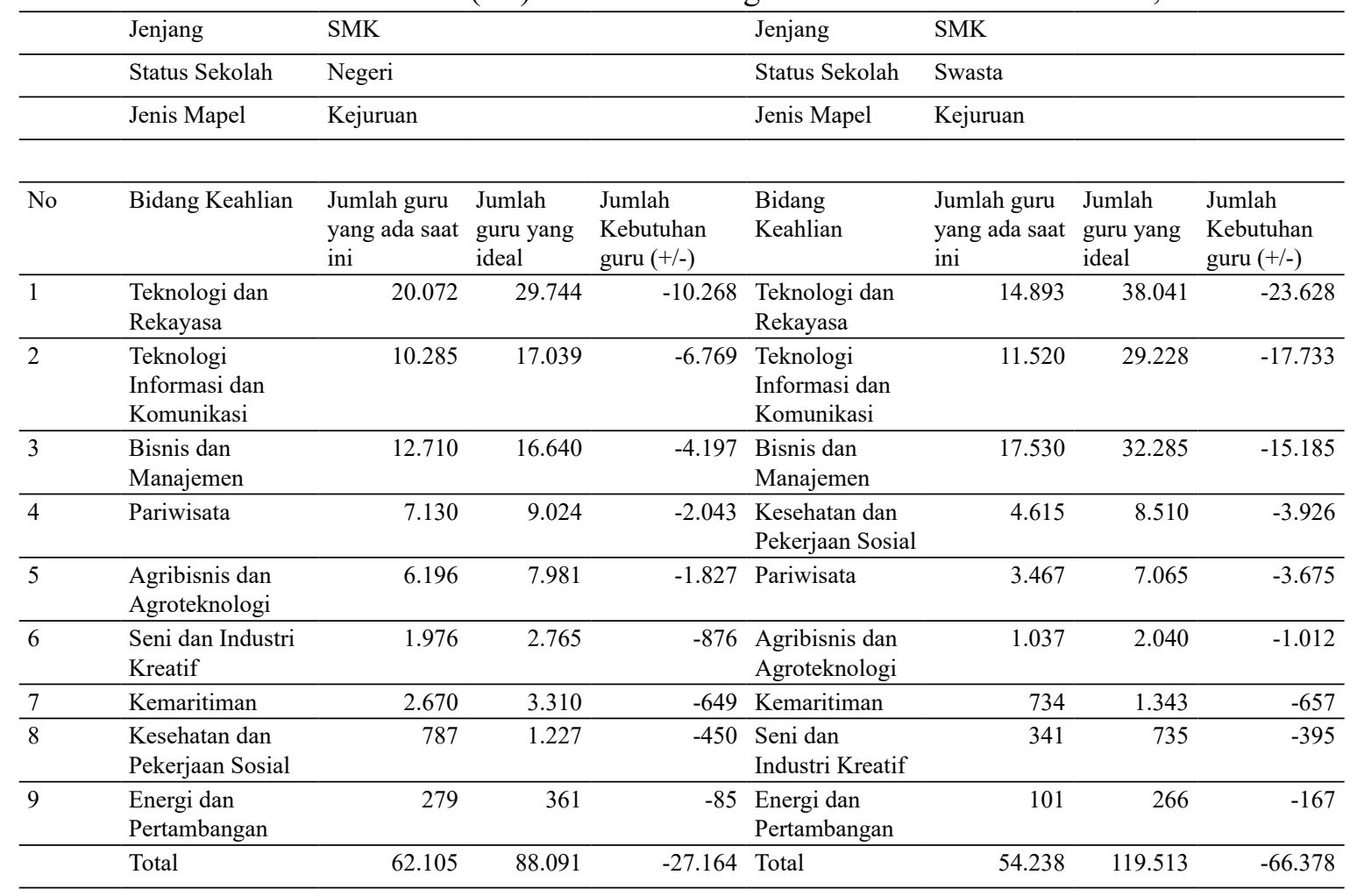

Sumber Data: Dapodik per 31 Desember 2018 (diolah Ditjen. GTK, Kemendikbud) 
Tidak semua sekolah mengalami kekurangam guru, tapi ada juga sekolah yang kelebihan guru atau tidak kekurangan guru-tidak kelebihan guru (Tabel 6). Bidang keahlian Teknologi dan Rekayasa adalah bidang keahlian yang sekolahnya banyak kekurangan guru, baik di SMK negeri maupun swasta.

Tabel 6. Persentase SMK Menurut Kondisi Guru Peminatan Kejuruan, Tahun 2018

\begin{tabular}{|c|c|c|c|c|c|}
\hline & Jenjang & SMK & & & \\
\hline & Status Sekolah & Negeri & & & \\
\hline & Jenis Mapel & Kejuruan & & & \\
\hline \multirow[b]{2}{*}{ No } & \multirow[b]{2}{*}{ Bidang Keahlian } & \multirow[b]{2}{*}{$\begin{array}{l}\text { Jumlah } \\
\text { Sekolah }\end{array}$} & \multicolumn{3}{|l|}{ Kondisi Guru } \\
\hline & & & $\begin{array}{l}\text { Kekurangan } \\
\text { Guru }\end{array}$ & $\begin{array}{l}\text { Tidak Kekurangan Guru Tidak } \\
\text { Kelebihan Guru }\end{array}$ & $\begin{array}{l}\text { Kelebihan } \\
\text { Guru }\end{array}$ \\
\hline 1 & Teknologi dan Rekayasa & 1.997 & 81,77 & $\begin{array}{rr}10,92 \\
\end{array}$ & 7,31 \\
\hline 2 & $\begin{array}{l}\text { Teknologi Informasi dan } \\
\text { Komunikasi }\end{array}$ & 2.233 & 76,22 & 15,14 & 8,64 \\
\hline 3 & Kesehatan dan Pekerjaan Sosial & 211 & 69,67 & 15,64 & 14,69 \\
\hline 4 & Seni dan Industri Kreatif & 243 & 67,49 & 17,28 & 15,23 \\
\hline 5 & Bisnis dan Manajemen & 1.510 & 65,56 & 15,76 & 18,68 \\
\hline 6 & Pariwisata & 835 & 64,55 & 16,53 & 18,92 \\
\hline 7 & Agribisnis dan Agroteknologi & 1.152 & 57,20 & 21,01 & 21,79 \\
\hline 8 & Kemaritiman & 546 & 53,11 & 20,33 & 26,56 \\
\hline \multirow[t]{4}{*}{9} & Energi dan Pertambangan & 100 & 52,00 & 27,00 & 21,00 \\
\hline & Jenjang & SMK & & & \\
\hline & Status Sekolah & Swasta & & & \\
\hline & Jenis Mapel & Kejuruan & & & \\
\hline \multirow[b]{2}{*}{ No } & \multirow[b]{2}{*}{ Bidang Keahlian } & \multirow[b]{2}{*}{$\begin{array}{l}\text { Jumlah } \\
\text { Sekolah }\end{array}$} & \multicolumn{2}{|c|}{ Kondisi Guru } & \\
\hline & & & $\begin{array}{l}\text { Kekurangan } \\
\text { Guru }\end{array}$ & $\begin{array}{l}\text { Tidak Kekurangan Guru dan Tidak } \\
\text { Kelebihan Guru }\end{array}$ & $\begin{array}{l}\text { Kelebihan } \\
\text { Guru }\end{array}$ \\
\hline \multirow[t]{2}{*}{1} & Teknologi dan Rekayasa & 4.326 & 91,86 & 5,92 & 2,22 \\
\hline & $\begin{array}{l}\text { Teknologi Informasi dan } \\
\text { Komunikasi }\end{array}$ & 5.455 & 86,32 & 9,99 & 3,68 \\
\hline 3 & Seni dan Industri Kreatif & 186 & 80,11 & 13,98 & 5,91 \\
\hline 4 & Energi dan Pertambangan & 68 & 79,41 & 13,24 & 7,35 \\
\hline 5 & Kemaritiman & 255 & 78,04 & 11,37 & 10,59 \\
\hline 6 & Pariwisata & 1.286 & 77,29 & 13,92 & 8,79 \\
\hline 7 & Kesehatan dan Pekerjaan Sosial & 1.406 & 77,29 & 13,92 & 8,79 \\
\hline 8 & Bisnis an Manajemen & 4.683 & 77,13 & 12,53 & 10,34 \\
\hline 9 & Agribisnis dan Agroteknologi & 587 & 75,13 & 13,29 & 11,58 \\
\hline
\end{tabular}

Sumber Data: Dapodik per 31 Desember 2018 (diolah Ditjen. GTK, Kemendikbud)

1.2. Upaya Pemenuhan Kebutuhan Guru Peminatan Kejuruan

Upaya-upaya yang telah/sedang dilakukan oleh pemerintah, pemerintah daerah provinsi, pemerintah daerah kabupaten/kota, sekolah, bahkan Perguruan Tinggi (PT) dalam memenuhi kebutuhan guru peminatan kejuruan, tapi sampai saat ini masih kekurangan guru peminatan kejuruan. Upaya-upaya dimaksud antara lain adalah: 
Tabel 7. Upaya-Upaya Yang Telah/Sedang Dilakukan Guna Pemenuhan Kebutuhan Guru Peminatan Kejuruan

\begin{tabular}{|c|c|c|c|c|c|c|c|}
\hline \multirow[b]{2}{*}{ No } & \multirow{2}{*}{\multicolumn{2}{|c|}{$\begin{array}{l}\text { Upaya-upaya yang telah/sedang dilakukan guna pemenuhan Kebutuhan } \\
\text { guru SMK }\end{array}$}} & \multicolumn{5}{|c|}{ Penyelenggara } \\
\hline & & & \multirow{2}{*}{$\begin{array}{l}\text { Pemerintah } \\
\sqrt{ } \\
\end{array}$} & $\begin{array}{c}\text { Pemerintah } \\
\text { Provinsi }\end{array}$ & \multirow[t]{2}{*}{$\begin{array}{c}\text { Pemerintah } \\
\text { Kab/Kota }\end{array}$} & Sekolah & \multirow[t]{2}{*}{ PT } \\
\hline 1 & Rekrutmen guru PNS & & & & & & \\
\hline 2 & $\begin{array}{l}\text { Rekrutmen } \\
\text { Honorer }\end{array}$ & & & $\sqrt{ }$ & $\sqrt{ }$ & $\sqrt{ }$ & \\
\hline 3 & $\begin{array}{lr}\text { Rekrutmen } & \text { guru } \\
\text { Pegawai } & \text { Pemerintah } \\
\text { dengan } & \text { Perjanjian } \\
\text { Kerja (guru PPPK) }\end{array}$ & $\begin{array}{l}\text { ·UU Nomor } 5 \text { Tahun } 2014 \text { Tentang } \\
\text { Aparatur Sipil Negara, Pasal } 6 \\
\text { menyatakan bahwa selain Pegawai } \\
\text { Negeri Sipil yang selanjutnya disingkat } \\
\text { PNS, adapula Pegawai Pemerintah } \\
\text { dengan Perjanjian Kerja yang selanjutnya } \\
\text { disingkat PPPK. } \\
\text {-PPPK merupakan pegawai ASN yang } \\
\text { diangkat sebagai pegawai dengan } \\
\text { perjanjian kerja oleh Pejabat Pembina } \\
\text { Kepegawaian sesuai dengan kebutuhan } \\
\text { Instansi Pemerintah dan ketentuan } \\
\text { Undang-Undang ini. } \\
\text { - PPPK berhak memperoleh:gaji dan } \\
\text { tunjangan, cuti, perlindungan, dan } \\
\text { pengembangan kompetensi. }\end{array}$ & $\begin{array}{l} \\
\sqrt{ } \\
\\
\\
\end{array}$ & & & & \\
\hline 4 & $\begin{array}{lr}\text { Program } & \text { Keahlian } \\
\text { Ganda } & \text { Kementerian } \\
\text { Pendidikan } & \text { dan } \\
\text { K e b u d a y a a n }, \\
\text { Direktorat } & \text { Jenderal } \\
\text { Pendidikan } & \text { Dasar dan } \\
\text { Menengah, Direktorat } \\
\text { Pembinaan } & \text { Sekolah } \\
\text { Menengah Kejuruan, } \\
\text { 2017) }\end{array}$ & $\begin{array}{l}\text { Program Keahlian Ganda adalah } \\
\text { program pemberian tambahan } \\
\text { kewenangan mengajar bagi guru SMK/ } \\
\text { SMA yang mengajar mata pelajaran } \\
\text { tertentu menjadi guru mata pelajaran } \\
\text { produktif di SMK pada kompetensi } \\
\text { keahlian tertentu yang berbeda dengan } \\
\text { kompetensi keahlian sebelumnya } \\
\text { dan relevan dengan latar belakang } \\
\text { pendidikannya } \\
\text { Pemberian kewenangan mengajar } \\
\text { pada paket keahlian yang baru bagi } \\
\text { guru SMK/SMA dilakukan setelah guru } \\
\text { mengikuti tahapan proses pendidikan } \\
\text { dan pelatihan (diklat) melalui pola } \\
\text { "ON-1 IN-1 ON-2 dan IN-2" dan } \\
\text { diakhiri dengan sertifikasi keahlian } \\
\text { di Lembaga Sertifikasi Profesi (LSP) } \\
\text { untuk memperoleh sertifikat keahlian } \\
\text { dan sertifikasi melalui Pendidikan dan } \\
\text { Latihan Profesi Guru (PLPG) di LPTK } \\
\text { untuk memperoleh sertifikat pendidik }\end{array}$ & $\sqrt{ }$ & & & & \\
\hline 5 & $\begin{array}{l}\text { Yahya, } \quad \text { M (2016) } \\
\text { dalam penelitiannya } \\
\text { m e n g e m u k a k a n } \\
\text { beberapa progran yang } \\
\text { dapat dilakukan antara } \\
\text { Dirjen } \\
\text { adalah: }\end{array}$ & & $\sqrt{ }$ & & & & $\sqrt{ }$ \\
\hline & $\begin{array}{l}\text { Program talent } \\
\text { scouting, }\end{array}$ & $\begin{array}{l}\text { Program yang melibatkan mahasiswa } \\
\text { tingkat akhir mengajar pada SMK } \\
\text { yang kekurangan guru selama } 6 \text { bulan. } \\
\text { Progran ini dapat dilakukan kerja sama } \\
\text { antara Ditjen GTK. Program ini pernah } \\
\text { dilaksanakan oleh P2TK Dikmen } \\
\text { Kemdikbud dengan LPTK }\end{array}$ & & & & & \\
\hline
\end{tabular}




\begin{tabular}{|c|c|c|c|c|c|c|c|}
\hline \multirow[b]{2}{*}{ No } & \multirow{2}{*}{\multicolumn{2}{|c|}{$\begin{array}{l}\text { Upaya-upaya yang telah/sedang dilakukan guna pemenuhan Kebutuhan } \\
\text { guru SMK }\end{array}$}} & \multicolumn{5}{|c|}{ Penyelenggara } \\
\hline & & & \multirow[b]{2}{*}{ Pemerintah } & \multirow[t]{2}{*}{$\begin{array}{l}\text { Pemerintah } \\
\text { Provinsi }\end{array}$} & \multirow[t]{2}{*}{$\begin{array}{c}\text { Pemerintah } \\
\text { Kab/Kota }\end{array}$} & \multirow[t]{2}{*}{ Sekolah } & PT \\
\hline & $\begin{array}{l}\text { Progam sarjana } \\
\text { mengajar }\end{array}$ & $\begin{array}{l}\text { Program yang menugaskan lulusan } \\
\text { LPTK Teknik mengajar pada SMK yang } \\
\text { kekurangan guru selama } 6 \text { bulan atau } 12 \\
\text { bulan. Program ini dapat dilakukan kerja } \\
\text { sama antara Dirjen GTK dengan LPTK } \\
\text { Teknik. Progam ini pula pemah dilakukan } \\
\text { kerja sama antam P2TK Dikmen } \\
\text { Kemdikbud dengan LPTK Teknik dan } \\
\text { hasilnya sangat membantu permasalahan } \\
\text { kekurangan guru di SMK }\end{array}$ & & & & & \\
\hline & $\begin{array}{l}\mathrm{P} \quad \mathrm{r} \quad \mathrm{o} \quad \mathrm{g} \quad \mathrm{r} \text { a } \mathrm{m} \\
\text { pendampingan } \\
\text { adalah: }\end{array}$ & & & & & & \\
\hline & $\begin{array}{l}\text { o Program PPL } \\
\text { (Praktik Pengalaman } \\
\text { Lapangan) }\end{array}$ & $\begin{array}{l}\text { Pendampingan guru produktif SMK, } \\
\text { adalah program dengan melibatkan } \\
\text { mahasiswa tingkat akhir PPL selama } 6 \\
\text { bulan ke SMK rujukan. Program ini dapat } \\
\text { dilakukan kerjasama antara Dirjen GTK } \\
\text { dengan LPTK Teknik dan Vokasi }\end{array}$ & & & & & \\
\hline & $\begin{array}{l}\text { o P r o g a m } \\
\text { pendampingan } \text { SMK } \\
1 \text { tahun dengan } \\
\text { melibatkan lulusan } \\
\text { LPTK yang telah } \\
\text { lulus sertifikasi (guru } \\
\text { profesional, tapi belum } \\
\text { diangkat PNS). Progran } \\
\text { ini dapat dilakukan } \\
\text { kerjasama antara Dirjen } \\
\text { Guru dengan LPTK }\end{array}$ & & & & & & \\
\hline & $\begin{array}{l}\text { Progam pemanfaatan } \\
\text { tenaga ahli industri, } \\
\text { merekrut tenaga ahli } \\
\text { Industri dan purna } \\
\text { bakti melalui program } \\
\text { RPL (Recognition } \\
\text { Prior Learning/ } \\
\text { Pengakuan Pengalaman } \\
\text { Masa Lampau) guru } \\
\text { produktif SMK. }\end{array}$ & & & & & & \\
\hline & $\begin{array}{l}\text { Program SM3T gpru } \\
\text { Produktif SMK, }\end{array}$ & $\begin{array}{l}\text { Program pemenuhan kebutuhan guru } \\
\text { yang sangat perlu dilakukan. Program } \\
\text { ini pernah dilaksanakan kerja sama } \\
\text { antara Direktorat P2TK Dikmen dengan } \\
\text { LPTK Teknik dengan melibatkan lulusan } \\
\text { LPTK selama } 12 \text { bulan (1 tahun) pada } \\
\text { SMK wilayah 3T, namun program ini } \\
\text { tidak berlanjut. Program ini dipandang } \\
\text { sejalan dan sangat tepat dengan kebijakan } \\
\text { pemerintah saat ini dalam penyiapan } \\
\text { Guru. }\end{array}$ & & & & & \\
\hline & $\begin{array}{l}\text { Progam alih status } \\
\text { guru produktif SMK }\end{array}$ & $\begin{array}{l}\text { Pengalihan tenaga kependidikan dan } \\
\text { tenaga adminisftasi yang memenuhi } \\
\text { persyaratan menjadi guru produktif SMK }\end{array}$ & & & & & \\
\hline & $\begin{array}{l}\text { Program alih fungsi/ } \\
\text { spesialisasi }\end{array}$ & $\begin{array}{l}\text { Upaya penyesuaian kompetensi keahlian } \\
\text { guru produktif SMK untuk memenuhi } \\
\text { kekurangan dan ketidaktersediaan guru } \\
\text { pada program keahlian tertentu }\end{array}$ & & & & & \\
\hline
\end{tabular}




\section{Pembahasan}

Dalam uraian sebelumnya dinyatakan bahwa kebutuhan guru peminatan kejuruan dalam kategori kekurangan guru, baik di SMK negeri maupun swasta. Kekurangan guru peminatan kejuruan terjadi di tiap provinsi maupun bidang keahlian. Banyak faktor yang mempengaruhi kebutuhan guru, antara lain: enrollment sekolah, mutasi siswa, siswa drop out, jumlah jam per minggu yang diterima siswa masing-masing mata pelajaran tertentu maupun seluruh mata pelajaran, beban mengajar penuh guru per minggu, besar kelas yang dianggap efektif untuk menerima suatu mata pelajaran, jumlah guru yang ada, jumlah guru yang akan pensiun atau berhenti atau karena sesuatu hal akan meninggalkan jabatan keguruan, dan jenis sekolah dan jenjang sekolah yang memerlukan guru.

Peranan guru selaku pendidik profesional dengan tugas utama mendidik, mengajar, membimbing, mengarahkan, melatih, menilai, dan mengevaluasi peserta didik pada pendidikan anak usia dini jalur pendidikan formal, pendidikan dasar, dan pendidikan menengah bertugas membantu peserta didik agar dapat belajar dengan baik dan mudah. Dengan demikian, tanpa guru, pendidikan hanya akan menjadi slogan muluk karena segala bentuk kebijakan dan program pada akhirnya akan ditentukan oleh kinerja pihak yang berada di garis terdepan, yaitu guru (Wiharna, 2006:64 dalam Triwiyanto, T., Desi Eri Kusumaningrum, dan Imam Gunawan, 2017).

Kekurangan guru peminatan kejuruan akan mempengaruhi kualitas pembelajaran. Kualitas pembelajaran dapat dilihat dari segi proses dan hasil. Dari segi proses, pembelajaran dikatakan berhasil dan berkualitas apabila seluruhnya atau setidaktidaknya sebagian besar peserta didik terlibat secara aktif baik fisik, mental maupun sosial dalam proses pembelajaran, disamping menunjukkan kegairahan belajar yang tinggi, semangat belajar yang besar, dan rasa percaya pada diri sendiri. Sedangkan dari segi hasil, proses pembelajaran dikatakan berhasil apabila terjadi perubahan tingkah laku yang positif pada diri peserta didik seluruhnya atau setidak-tidaknya sebagian besar (Mulyasa, 2003 dalam Memorata, A dan Djoko Santoso (tanpa tahun).

Terkait dengan hasil pembelajaran SMK dapat dilihat dari kondisi ketenagakerjaan lulusan SMK. Penjelasan pasal 15 UU Nomor 20 Tahun 2003 Tentang Sistem Pendidikan Nasional menyatakan bahwa pendidikan kejuruan merupakan pendidikan menengah yang mempersiapkan peserta didik terutama untuk bekerja dalam bidang tertentu. Kondisi ketenagakerjaan lulusan SMK disajikan dalam tabel 8 yang memperlihatkan bahwa belum semua lulusan baru SMK bekerja. Sekitar 55,01\% lulusan laki-laki bekerja, sedangkan lulusan perempuan yang bekerja mencapai 65,89\%. Lulusan perempuan lebih besar dibandingkan lulusan laki-laki.

Tabel 8. Persentase Lulusan Baru SMK Menurut Kegiatan Seminggu Yang Lalu dan Jenis Kelamin, Tahun 2019

\begin{tabular}{llrr}
\hline \multirow{2}{*}{ No } & \multirow{2}{*}{$\begin{array}{l}\text { Kegiatan Seminggu } \\
\text { yang Lalu }\end{array}$} & \multicolumn{2}{l}{ Jenis Kelamin } \\
\cline { 2 - 4 } & Laki-Laki & Perempuan \\
\hline 1 & Bekerja & 55,01 & 65,89 \\
\hline 2 & Penganggur & 28,02 & 13,67 \\
\hline 3 & Sekolah & 7,68 & 7,01 \\
\hline \multirow{2}{*}{4} & $\begin{array}{l}\text { Mengurus rumah } \\
\text { tangga }\end{array}$ & 4,72 & 11,97 \\
\hline 5 & Lainnya & 4,56 & 1,45 \\
\hline & Total & $\mathbf{1 0 0 , 0 0}$ & $\mathbf{1 0 0 , 0 0}$ \\
\hline
\end{tabular}

Sumber Data: Survei Angkatan Kerja Nasional (Sakernas), Februari 2019 
Kualitas pembelajaran SMK tidak hanya ditentukan oleh jumlah gurunya (kuantitas), tetapijuga kualitas gurunya. Dengan guru yang berkualitas, maka guru mampu menghadapi tantangan pengembangan Sumber Daya Manusia (SDM), seperti tantangan revolusi industri 4.0. Industri 4.0 adalah trend di dunia industri yang menggabungkan teknologi otomatisasi dengan teknologi cyber. Tren ini telah mengubah banyak bidang kehidupan manusia, termasuk ekonomi, dunia kerja, bahkan gaya hidup manusia itu sendiri. Singkatnya, revolusi 4.0 menanamkan teknologi cerdas yang dapat terhubung dengan berbagai bidang kehidupan manusia. Revolusi industri 4.0 akan membawa banyak perubahan dengan segala konsekuensinya, industri akan semakin kompak dan efisien. Namun ada pula risiko yang mungkin muncul, misalnya berkurangnya SDM karena digantikan oleh mesin atau robot (https:// www.maxmanroe.com/ revolusi-industri-4-0. html. diakses 4 September 2019).

Kualitas guru diatur dalam UU Nomor 14 Tahun 2005 Tentang Guru dan Dosen. Guru wajib memiliki kualifikasi akademik, kompetensi, sertifikat pendidik, sehat jasmani dan rohani, serta memiliki kemampuan untuk mewujudkan tujuan pendidikan nasional. Kualifikasi akademik diperoleh melalui pendidikan tinggi program sarjana atau program diploma empat. Kompetensi guru meliputi kompetensi pedagogik, kompetensi kepribadian, kompetensi sosial, dan kompetensi profesional yang diperoleh melalui pendidikan profesi. Kompetensi guru diukur dengan Uji Kompetensi Guru (UKG). UKG pernah dilaksanakan tahun 2015 oleh Ditjen. GTK. Sertifikat pendidik diberikan kepadaguru yangtelahmemenuhipersyaratan.
Sertifikasi pendidik diselenggarakan oleh perguruan tinggi yang memiliki program pengadaan tenaga kependidikan yang terakreditasi dan ditetapkan oleh Pemerintah. Kondisi kualitas guru SMK disajikan dalam tabel 9.

Tabel 9. Kondisi Kualitas Guru SMK Berdasarkan UU Nomor 14 Tahun 2005

\begin{tabular}{|c|c|c|c|}
\hline \multirow[b]{2}{*}{ No } & \multirow[b]{2}{*}{ Kualitas Guru } & \multicolumn{2}{|c|}{ Status Sekolah } \\
\hline & & $\begin{array}{l}\text { SMK } \\
\text { Negeri }\end{array}$ & $\begin{array}{l}\text { SMK } \\
\text { Swasta }\end{array}$ \\
\hline 1 & $\begin{array}{l}\text { Persentase guru } \\
\text { peminatan kejuruan } \\
\text { yang berpendidikan } \geq \\
\text { D4/S1 tahun } 2018^{*}\end{array}$ & 97,10 & 90,42 \\
\hline 2 & $\begin{array}{l}\text { Persentase guru } \\
\text { peminatan kejuruan } \\
\text { yang sudah sertifikasi } \\
\text { tahun } 2018^{*}\end{array}$ & 49,73 & 27,86 \\
\hline 3 & $\begin{array}{l}\text { Nilai rata-rata Ujian } \\
\text { Kompetensi Guru } \\
\text { (UKG) SMK tahun } \\
\text { 2015** }\end{array}$ & 60,33 & 57,91 \\
\hline
\end{tabular}

Sumber Data:

* Dapodik per 31 Desember 2018 (diolah Ditjen. GTK, Kemendikbud)

** Ditjen. GTK tahun 2015

\section{SIMPULAN DAN OPSI KEBIJAKAN}

\section{Simpulan}

Kebutuhan guru peminatan kejuruan masuk dalam ketegori kekurangan guru. Kekurangan guru peminatan kejuruan di SMK negeri lebih kecil dibandingkan di SMK swasta. Kekurangan guru peminatan kejuruan terjadi di tiap provinsi maupun bidang keahlian. Faktor yang mempengaruhi kebutuhan guru, antara lain: enrollment sekolah, mutasi siswa, siswa drop out, jumlah jam per minggu yang diterima siswa masingmasing mata pelajaran tertentu maupun seluruh mata pelajaran, beban mengajar penuh guru per minggu, besar kelas yang dianggap efektif untuk menerima suatu mata pelajaran, jumlah guru yang ada, jumlah guru yang akan 
pensiun atau berhenti atau karena sesuatu hal akan meninggalkan jabatan keguruan, dan jenis sekolah dan jenjang sekolah yang memerlukan guru. Upaya pemenuhan guru peminatan kejuruan telah dilakukan oleh pemerintah, antara lain: rekrutmen guru PNS, rekrutmen guru honorer, maupun program keahlian ganda, tetapi masih memerlukan pemikiran lebih lanjut untuk mengatasinya.

Kekurangan guru peminatan kejuruan akan mempengaruhi kualitas pembelajaran. Guru berhubungan langsung dalam proses pembelajaran di kelas. Guru memiliki peran yang penting dalam meingkatkan kualitas anak didiknya. Dengan persentase guru normatif-adaptif yang lebih tinggi dibandingkan pengajar yang memang secara khusus memiliki kompetensi di bidang kejuruannya, hal ini bisa menjadi salah satu ancaman rendahnya daya saing lulusan SMK.

Kualitas pembelajaran SMK tidak hanya ditentukan oleh jumlah gurunya (kuantitas), tetapi juga kualitas gurunya. Selain itu, gurupun dituntut kemampuannya menghadapi tantangan pengembangan Sumber Daya Manusia (SDM), antara lain: tantangan bonus demografi, revolusi industri 4.0, generasi $\mathrm{Z}$ dan Alpa, serta isu nasional.

\section{USULAN KEBIJAKAN}

Oleh karena di SMK masih mengalami kekurangan guru peminatan kejuruan, maka upaya pemenuhannya dapat dilakukan melalui:

- Rekrutmen guru Pegawai Pemerintah dengan Perjanjian Kerja (PPPK) yang sekarang sedang berlangsung diprioritaskan untuk memenuhi kebutuhan guru peminatan kejuruan. Hal ini selaras dengan upaya revitalisasi SMK dalam meningkatkan kualitas dan daya saing SDM Indonesia.

- Kerjasama Kemendikbud dengan Perguruan Tinggi (PT). Ini dapat dilakukan mengingat PT mempunyai Tridharma Perguruan Tinggi, yang salah satunya dan pengabdian kepada masyarakat (UU Nomor 12 Tahun 2012 Tentang Pendidikan Tinggi). Kerjasamanya dengan melibatkan dosen di universitas/politeknik dalam pemenuhan guru peminatan kejuruan. Kelebihan upaya ini adalah calon pengajar di universitas/ politeknik tersedia banyak, sedangkan kekurangannya adalah calon pengajar kurang dalam hal kompetensi yang dibutuhkan Dunia Usaha/Dunia Industri (DUDI), sehingga perlu dilatih terlebih dahulu.

- Kerjasama Kemendikbud dengan DUDI. Ini dapat dilakukan menfaatkan orang yang memiliki keterampilan teknis yang berasal dari dunia usaha/industri yang melatih dan membimbing peserta didik dalam meningkatkan keterampilan teknis pembelajaran di SMK. Kelebihan upaya ini adalah calon pengajar di DUDI tersedia banyak, sedangkan kekurangannya adalah calon pengajar kurang dalam hal kompetensi kompetensi pedagogik, sehingga perlu dilatih terlebih dahulu.

- Kerjasama Kemendikbud dengan orang-orang yang memiliki pengetahuan dan keterampilan tapi tidak mempunyai sertifikat formal mengajar untuk melakukan pembelajaran di SMK. Kelebihan upaya ini adalah calon pengajar yang memiliki pengetahuan dan keterampilan tersedia banyak, sedangkan kekurangannya adalah calon pengajar kurang dalam hal kompetensi pedagogik, sehingga perlu dilatih terlebih dahulu. 


\section{DAFTAR PUSTAKA}

Amirin, T. M (2015). Metode Penelitian Sekunder (Analisis Data Sekunder), https:// tatangmanguny.wordpress.com/2015/04/ 12/metode-penelitian-sekunder-analisis-datasekunder/. diakses 14 Juni 2019

Chandra I, Aunurrahman, Herculanus Bahari Sindju (tanpa tahun). Proyeksi Kebutuhan Guru SMP, SMA, Dan SMK Di Kecamatan Paloh Kabupaten Sambas Tahun 2016/2017, http:// jurnal.untan.ac.id/index.php/jpdpb/article/view/6302/7181, diakses 2 September 2019

Inpres No. 9 Tahun 2016 Tentang Revitalisasi Sekolah Menengah Kejuruan Dalam Meningkatkan Kualitas Dan daya Saing Sumber Daya Manusia Indonesia

Kementerian Pendidikan dan Kebudayaan, Direktorat Jenderal Pendidikan Dasar dan Menengah, Direktorat Pembinaan Sekolah Menengah Kejuruan. (2017). Pola Kebijakan Pengembangan Guru Produktif Berdasarkan Inpres Nomor 9 Tahun 2016

Kusrini, E. (2014). Proyeksi Kebutuhan Guru Kelompok Produktif Sekolah Menengah Kejuruan (SMK) Rumpun Bisnis Dan Manajemen (BISMAN) 2014/2015-2023/2024 Di Kabupaten Kulon Progo. Skripsi. Yoyakarta: Program Studi Manajemen Pendidikan Jurusan Administrasi Pendidikan Fakultas Ilmu Pendidikan Universitas Negeri Yogyakarta

Memorata, A dan Djoko Santoso. (tanpa tahun). Peningkatan Kualitas Pembelajaran Dan Hasil Belajar Merakit Personal Komputer Menggunakan Structured Dyadic Methods (SDM), http://journal.student.uny.ac.id/ojs/index.php/pti/article/view/7862/pdf. diakses 3 September 2019

Mulyadi, Y., Agus Setiawan, dan Purnawan (2010). Studi Evaluasi Kebutuhan Guru Sekolah Menengah Kejuruan Di Propinsi Bangka Belitung dalam Proceedings of The 4th International Conference on Teacher Education; Join Conference UPI \& UPSI Bandung, Indonesia, 8-10 November 2010, http://file.upi.edu/Direktori/PROCEEDING/UPIUPSI/2010/Book_5/STUDI_EVALUASI_KEBUTUHAN_GURU_SEKOLAH MENENGAH_KEJURUAN_DI_PROPINSI_BANGKA_BELITUNG.PDF. diakses 3 September 2019

Peraturan Direktur Jenderal Pendidikan Dasar Dan Menengah Kementerian Pendidikan Dan Kebudayaan Nomor: 06/D.D5/KK/2018 Tentang Spektrum Keahlian Sekolah Menengah Kejuruan (SMK)/Madrasah Aliyah Kejuruan (MAK)

Peraturan Direktur Jenderal Pendidikan Dasar Dan Menengah Nomor: 07/D.D5/Kk/2018 Tentang Struktur Kurikulum Sekolah Menengah Kejuruan (SMK)/Madrasah Aliyah Kejuruan (MAK)

Permendiknas Nomor 22 Tahun 2006 Tentang Standar Isi Untuk Satuan Pendidikan Dasar Dan Menengah

Permendikbud Nomor 34 Tahun 2018 Tentang Standar Nasional Pendidikan Sekolah Menengah Kejuruan/Madrasah Aliyah Kejuruan: Standar Pendidik Dan Tenaga Kependidikan

Revolusi Industri 4.0: Pengertian, Prinsip, Dan Tantangan Generasi Milenial, https://www. maxmanroe.com/revolusi-industri-4-0.html. diakses 4 September 2019

Triwiyanto, T., Desi Eri Kusumaningrum, dan Imam Gunawan (2017). Proyeksi Ketersediaan, Kebutuhan, Dan Distribusi Guru Sekolah Menengah Pertama Di Kota Batu dalam 
Laporan Penelitian Penelitian Pnbp Jurusan. Fakutas Ilmu Pendidikan, Universitas Negeri Malang November, 2017

UU Nomor 20 Tahun 2003 Tentang Sistem Pendidikan Nasional

UU Nomor 14 Tahun 2005 Tentang Guru dan Dosen

UU Nomor 5 Tahun 2014 Tentang Aparatur Sipil Negara

Yahya, M. (2016). Strategi Pemenuhan Kebutuhan Guru Produktif SMK dalam Prosiding Kovensi Nasional Pendidikan Indonesia (KONASPI) Vlll Tahun 2016: Arah Kebijakan Pendidikan Guru di Indonesia, http://eprints.unm.ac.id/1689/1/Prosiding\%20 Konaspi\%20VIII.pdf, diakses 3 September 2019

Yulius, Muhammad Isran, Mardhianda WP , dan Bangkit Anugerah. (2017). Roadmap Kebijakan Pengembangan Vokasi di Indonesia 2017-2025. Kementerian Koordinator Bidang Perekonomian 